\title{
Pengaruh Kualitas Kehidupan Kerja dan Motivasi terhadap Kinerja Pegawai melalui Kepuasan Kerja di Universitas Palangka Raya
}

\author{
Antoni Yahya Christiadi ${ }^{1)}$ \\ Magister Sains Manajemen, \\ Universitas Palangka Raya \\ Ferdinand 2) \\ Fakultas Ekonomi dan Bisnis, \\ Universitas Palangka Raya \\ Stepanus ${ }^{3)}$ \\ Badan Pengembangan SDM, Kalimatan Tengah
}

Email: tonychrist7@yahoo.com

\begin{abstract}
Abstrak
Tujuan - Penelitian ini bertujuan untuk menguji dan menganalisis secara empiris pengaruh langsung kualitas kehidupan kerja dan motivasi terhadap kinerja, dan pengaruh tidak langsung kualitas kehidupan kerja dan motivasi terhadap kinerja melalui kepuasan kerja.

Desain/Metodelogi/Pendekatan - Metodologi Penelitian yang digunakan dalam penelitian ini adalah metode Deskriptif-Kuantitatif. Objek penelitian ini adalah 159 staf administrasi Universitas Palangka Raya yang berstatus Pegawai Negeri Sipil. Teknik analisis data menggunakan statistik deskriptif dan statistik inferensial. Data yang terkumpul dianalisis menggunakan Structural Equation Modeling (SEM) dengan pendekatan Partial Least Squares (PLS).

Temuan Penelitian - Hasil penelitian menunjukkan bahwa kualitas kehidupan kerja tidak berpengaruh langsung terhadap kinerja secara signifikan, motivasi tidak berpengaruh langsung terhadap kinerja secara signifikan, kepuasan kerja berpengaruh langsung terhadap kinerja secara signifikan, kualitas kehidupan kerja secara tidak langsung mempengaruhi kinerja secara signifikan melalui kepuasan kerja. dan motivasi secara tidak langsung berpengaruh signifikan terhadap kinerja melalui kepuasan kerja.
\end{abstract}

Orsinalitas/nilai - Menggunakan konsep kualitas kehidupan kerja dalam model yang digunakan.

Kata kunci: Kualitas Kehidupan Kerja, Motivasi, Kepuasan Kerja, Kinerja.

\section{The Impact of of Quality of Work Life and Motivation Against Employee Performance Through Job Satisfaction at Palangka Raya University)}

\section{Abstract}

Purpose - This study aims to test and analyze empirically the direct effect of work-life quality and motivation on performance, and the indirect influence of work-life quality and motivation on performance through job satisfaction.

Design / Methodology / Approach - The research methodology used in this research is descriptive-quantitative method. The object of this research is 159 administrative staff of Palangka Raya University who have the status of Civil Servants. The data analysis technique used descriptive statistics and inferential statistics. The collected data were analyzed using Structural Equation Modeling (SEM) with the Partial Least Squares (PLS) approach. Research Findings - The results showed that the quality of work life does not have a significant direct effect on performance, motivation does not have a significant direct effect on performance, job satisfaction has a significant direct effect on performance, and the quality of work life indirectly affects performance significantly through job satisfaction. Moreover, motivation indirectly has a significant effect on performance through job satisfaction.

Keywords: Quality of Work Life, Motivation, Job Satisfaction, Performance

Jurnal Manajemen Sains dan Organisasi Vol 1, No 1, 2020 pp. 64 - 75 FEB UPR
Antoni Yahya Christiadi, Ferdinand, Stepanus. Published in the Jurnal Manajemen sains dan Organsasi. Published by FEB UPR Publishing Limited. This article is published under the Creative Commons Attribution (CC BY 4.0) licence. Anyone may reproduce, distribute, translate and create derivative works of this article (for both commercial and non-commercial purposes), subject to full attribution to the original publication and authors. 


\section{PENDAHULUAN}

Dalam rangka menjawab tantangan dunia sekarang ini, organisasi harus selalu berupaya meningkatkan kemampuannya untuk menyerap dan menerapkan ilmu pengetahuan dan teknologi tersebut dalam organisasinya, sehingga organisasi akan selalu memiliki keunggulan bersaing untuk terus hidup dan berkembang. Dalam hal ini organisasi harus selalu meningkatkan kualitas kinerja para pegawai atau karyawannya agar mampu menjawab tantangan-tantangan dalam rangka pencapaian tujuan organisasi. Pada dasarnya kinerja karyawan merupakan hasil proses yang kompleks, baik berasal dari diri pribadi karyawan (internal factor) maupun upaya strategis dari perusahaan. Faktor-faktor internal misalnya motivasi, tujuan, harapan dan lain-lain, sementara faktor eksternal adalah lingkungan fisik dan non fisik perusahaan. Untuk mencapai kinerja pegawai atau karyawan yang baik tentunya organisasi harus memikirkan faktor-faktor penting yang dapat meningkatkan kinerja mereka. Salah satunya adalah dengan menciptakan kepuasan kerja bagi karyawannya.

Menurut Locke (dalam Luthans, 1998 (dalam Arifin, 2012) kepuasan kerja juga merupakan salah satu komponen dari kepuasan hidup. Sehingga hal tersebut menjadi sangat penting untuk diperhatikan dalam pengembangan dan pemeliharaan tenaga kerja. Karena jika karyawan tidak mendapatkan kepuasan dalam pekerjaannya, maka motivasi mereka akan menurun, absensi dan keterlambatan meningkat dan akan sulit untuk bekerja sama dengan mereka. Kepuasan kerja bagi karyawan tentunya tidak akan dapat tercapai apabila tidak ada motivasi atau dorongan yang dapat memberikan semangat untuk bekerja. Motivasi adalah faktor yang memberikan tenaga dan penyebab utama untuk menggerakan setiap makhluk hidup termasuk manusia. Karena, motivasi mengarah kepada fakta bahwa seseorang tetap berkomitmen untuk tugasnya dan melakukan pekerjaan dengan serius dan penuh kegembiraan (Azar dan Shafighi, 2013). Organisasi juga perlu menciptakan kondisi lingkungan kerja yang mampu memberikan kenyamanan untuk karyawannya dalam bekerja. Sumber daya manusia merupakan faktor yang sangat berharga, maka perusahaan bertanggungjawab untuk memelihara kualitas kehidupan kerja dan membina tenaga kerja agar bersedia memberikan kontribusinya secara optimal untuk mencapai tujuan perusahaan (Pruijt, 2003 dalam Arifin, 2012).

Berdasarkan latar belakang tersebut, maka rumusan masalah pada penelitian ini adalah untuk mengetahui pengaruh kualitas kehidupan kerja, motivasi dan kepuasan kerja secara langsung terhadap kinerja pegawai dan pengaruh kualitas kehidupan kerja dan motivasi secara tidak langsung terhadap kinerja dengan melalui kepuasan kerja.

\section{KAJIAN PUSTAKA}

\section{Hubungan Kualitas Kehidupan Kerja dengan Kepuasan Kerja}

Penelitian yang menunjukan adanya pengaruh kualitas kehidupan kerja terhadap kepuasan kerja. Penelitian Hasanmoradi (2011), menunjukkan para guru baik dari Sekolah Umum dan Non-Sekolah Umum berada dalam kondisi kualitas kehidupan kerja yang relatif tidak menguntungkan, tetapi mereka menikmati tingkat kepuasan kerja yang cukup tinggi. Ada hubungan positif dan signifikan antara faktor kualitas kehidupan kerja dan kepuasan kerja. Ada perbedaan yang signifikan dalam tingkat kualitas kehidupan kerja dan kepuasan kerja antara guru sekolah umum dan non-sekolah umum. Sedangkan penelitian Arifin (2012), menyimpulkan bahwa kualitas kehidupan kerja tidak berpengaruh terhadap kepuasan karyawan. Hal ini disebabkan kepuasan karyawan tidak hanya dipengaruhi kualitas kehidupan kerja, namun juga variabel-variabel lain seperti kepemimpinan, budaya organisasi dan motivasi.

\section{Hubungan Motivasi dengan Kepuasan Kerja}

Penelitian Brahmasari (2008), diperoleh kesimpulan bahwa motivasi kerja, kepemimpinan dan budaya organisasi berpengaruh positif dan signifikan terhadap kepuasan kerja. Kemudian kepemimpinan, budaya organisasi dan kepuasan kerja berpengaruh positif dan signifikan terhadap kinerja. Dan motivasi kerja tidak berpengaruh signifikan terhadap kinerja perusahaan. Penelitian Chintalloo dan Mahadeo (2013), menyelidiki pengaruh motivasi pada kinerja karyawan. Kesimpulan penelitian bahwa terdapat hubungan yang signifikan antara motivasi dengan kinerja karyawan.

\section{Hubungan Kualitas Kehidupan Kerja dengan Kinerja}

Beberapa penelitian-penelitian terdahulu menunjukan adanya hubungan antara kualitas kehidupan kerja dan kinerja. Penelitian yang dilakukan Husnawati (2006), menunjukkan bahwa kualitas kehidupan kerja, komitmen dan kepuasan kerja mempunyai pengaruh langsung dan tidak langsung terhadap kinerja. Penelitian Majumdar et al. (2012), menyelidiki hubungan antara kualitas kehidupan kerja dan efeknya pada kinerja. 
Determinan variabel QWL meliputi budaya organisasi, hubungan kerja yaitu hubungan dengan atasan dan di antara rekan-rekan, pelatihan dan pengembangan fasilitas, sistem penghargaan, tunjangan, keamanan kerja, otonomi, variasi dalam jadwal kerja. Parameter Prestasi Kerja meliputi kedua dimensi keuangan dan non keuangan seperti rasio lancar, return on capital (ROCE), return on net worth/equity (ROE), rasio net profit margin dan return on asset (ROA) sedangkan indikator non keuangan menandakan standar kinerja individu. Hasil analisis dari lima perusahaan publik dan swasta dibawah Indian Service Industry, hanya satu perusahaan yang menunjukan rendahnya korelasi antara kualitas kehidupan kerja dan kinerja. Penelitian Arifin (2012), menyimpulkan bahwa kualitas kehidupan kerja sangat berpengaruh terhadap kinerja karyawan dan kepuasan berpengaruh terhadap kinerja karyawan kemudian kualitas kehidupan kerja tidak berpengaruh terhadap kepuasan karyawan.

\section{Hubungan Motivasi dengan Kinerja}

Penelitian Uche et al. (2011), meneliti hubungan antara faktor-faktor motivasi dan kinerja pada pekerjaan guru. Temuan menunjukkan bahwa ada hubungan yang signifikan antara faktor motivasi dan kinerja guru dan hubungan yang signifikan antara guru yang berpengalaman dan prestasi kerja karyawan. Penelitian Wiyono dan Hakim (2009), menganalisis dampak langsung dari kepemimpinan, motivasi, kemitraan, dan kepuasan terhadap kinerja, dan analisis dampak tidak langsung dari kepemimpinan, motivasi, dan kinerja melalui kepuasan. Hasil penelitian diperoleh kepemimpinan, motivasi, kemitraan, berdampak signifikan secara langsung dan tidak langsung terhadap kinerja. Dampak tidak langsung memiliki nilai lebih tinggi dari dampak langsung, dimana kepuasan sebagai variabel intervening.

\section{Hubungan Kepuasan Kerja dengan Kinerja}

Penelitian Hira dan Waqas (2012), melakukan studi untuk menjelaskan sifat hubungan antara kepuasan kerja dan prestasi kerja pada karyawan tingkat menengah sektor perbankan di Pakistan dengan latar belakang ekonomi Pakistan menghadapi krisis ekonomi 30 tahun terakhir dan sektor perbankan menunjukkan ketidakstabilan sejak tahun 2005. Hasil kesimpulan penelitian yaitu ada hubungan positif antara kepuasan kerja dan kinerja. Sedangkan penelitian Arifin (2012), dalam penelitiannya juga menganalisis pengaruh kepuasan kerja terhadap kinerja, menyimpulkan bahwa kepuasan berpengaruh terhadap kinerja karyawan.

\section{METODE PENELITIAN}

Dalam penelitian ini pendekatan yang digunakan adalah penelitian deskriptif-kuantitatif karena analisisnya akan menekankan pada data berbentuk numeric (angka). Populasi dalam penelitian ini adalah seluruh PNS bagian administrasi Universitas Palangka Raya yang berjumlah 263 orang. Sampel dalam penelitian ini adalah 159 pegawai bagian administrasi Universitas Palangka Raya. Metode sampling yang digunakan dalam penelitian ini adalah purposive sampling. Metode purposive sampling dipilih karena obyek sampel memenuhi kriteria yang diinginkan dalam penelitian ini. Kriteria obyek yang dipilih adalah pegawai Universitas Palangka Raya bagian administrasi yang berstatus PNS. Sedangkan untuk teknik pengambilan sampel yang menjadi perwakilan dari setiap unit sesuai dengan proporsi masing-masing unit digunakan proporsional random sampling.

Variabel yang dianalisis dalam penelitian ini meliputi variabel independen (variabel bebas) dan variabel dependen (terikat). Variabel independen (bebas) yaitu variabel X1, kualitas kehidupan kerja dan X2, motivasi. Variabel dependen (terikat) yaitu Y1, kepuasan kerja dan Y2, kinerja pegawai. Variabel Y1, kepuasan kerja dalam penelitian ini menjadi variabel intervening atau variabel mediasi (antara).

Untuk mendapatkan informasi dan data yang diperlukan dalam penelitian ini terkait objek penelitian maka teknik pengumpulan data dokumentasi dipergunakan. Dokumentasi yaitu mengumpulkan data informasi dengan mempelajari sumber data tertulis untuk memperoleh data sekunder tentang gambaran umum Universitas Palangka Raya, baik sejarah Universitas Palangka Raya, struktur organisasi, serta data tertulis lainnya yang terkait dengan penelitian ini.

\section{Pengukuran}

Untuk mendapatkan informasi dan data yang diperlukan dalam penelitian ini, maka akan digunakan kuesioner. Sedangkan untuk skala pengukuran dalam penelitian ini menggunakan Skala Likert dengan skor skala 1-5. Bentuk jawaban skala Likert yaitu : sangat setuju, setuju, ragu-ragu, tidak setuju dan sangat tidak setuju.

Teknik Analisis Data 
Analisis statistik inferensial digunakan untuk menguji pengaruh variabel kualitas kehidupan kerja, motivasi kerja, kepuasan kerja terhadap kinerja pegawai. Metode analisis data yang digunakan adalah Structural Equation Modeling (SEM) dengan pendekatan Partial Least Square (PLS). Sedangkan untuk menguji pengaruh kualitas kehidupan kerja terhadap kinerja secara tidak langsung melalui kepuasan kerja dan menguji pengaruh motivasi terhadap kinerja secara tidak langsung melalui kepuasan kerja, digunakan Sobel Test (Uji Sobel). Sobel Test bertujuan untuk mengetahui kekuatan pengaruh variabel independen terhadap variabel dependen melalui variabel intervening (mediasi).

\section{HASIL DAN PEMBAHASAN}

Responden dalam penelitian ini adalah tenaga administrasi Universitas Palangka Raya yang berstatus pegawai negeri sipil dimana sejumlah 159 pegawai diambil sebagai sampel untuk mewakili populasi yang ada. Dari 159 kuesioner yang disebar dari tanggal 10 Juni 2014 sampai dengan tanggal 25 Juni 2014, hanya 146 kuesioner yang telah diisi secara lengkap dan datanya dapat dipakai untuk dianalisis.

\section{Pengujian Convergent Validity}

Convergent validity mengukur besarnya korelasi antara konstruk dengan variabel laten. Suatu indikator dikatakan mempunyai validitas yang baik jika nilai loading factor lebih besar dari 0,7 sedangkan loading factor 0,5 sampai dengan 0,6 masih dianggap cukup bila digunakan untuk penelitian tahap awal dari pengembangan skala pengukuran. Chin 1998 (dalam Latan dan Ghozali, 2012). Hasil pengujian convergent validity ditunjukan dalam Tabel 1 berikut ini.

Tabel 1. Hasil Pengujian Convergent Validity

\begin{tabular}{|c|c|c|c|}
\hline Variabel & Indikator & $\begin{array}{l}\text { Loading Factor } \\
\text { (Outer Loadings) }\end{array}$ & Keterangan \\
\hline \multirow{5}{*}{$\begin{array}{c}\text { Kualitas } \\
\text { Kehidupan Kerja } \\
\text { (X1) }\end{array}$} & X1.1 & 0,677668 & Valid \\
\hline & $\mathrm{X} 1.2$ & 0,771605 & Valid \\
\hline & $\mathrm{X} 1.3$ & 0,728904 & Valid \\
\hline & X1.4 & 0,814110 & Valid \\
\hline & $\mathrm{X} 1.5$ & 0,652589 & Valid \\
\hline \multirow{4}{*}{$\begin{array}{l}\text { Motivasi } \\
\text { (X2) }\end{array}$} & X2.1 & 0,811283 & Valid \\
\hline & $\mathrm{X} 2.2$ & 0,876927 & Valid \\
\hline & $\mathrm{X} 2.3$ & 0,735059 & Valid \\
\hline & X2.4 & 0,835103 & Valid \\
\hline \multirow{4}{*}{$\begin{array}{c}\text { Kepuasan Kerja } \\
\text { (Y1) }\end{array}$} & Y1.1 & 0,619235 & Valid \\
\hline & Y1.2 & 0,758589 & Valid \\
\hline & Y1.3 & 0,773607 & Valid \\
\hline & Y1.4 & 0,784527 & Valid \\
\hline \multirow{4}{*}{$\begin{array}{l}\text { Kinerja } \\
\text { (Y2) }\end{array}$} & Y2.1 & 0,802479 & Valid \\
\hline & Y2.2 & 0,745653 & Valid \\
\hline & Y2.3 & 0,638783 & Valid \\
\hline & Y2.4 & 0,703714 & Valid \\
\hline
\end{tabular}

Sumber : Output SmartPLS 2.0 M3

Hasil analisis pada Tabel 1 diatas menunjukan hasil analisis setelah indikator konstruk yang tidak valid atau memiliki nilai dibawah 0,5 dikeluarkan dari model, dimana setelah dianalisis validitas diperoleh hasil bahwa seluruh indikator konstruk adalah valid atau memiliki nilai diatas 0,5 yang artinya memenuhi syarat convergent validity. 


\section{Pengujian Discriminant Validity}

Pengujian discriminant validity dilakukan dengan membandingkan akar kuadrat dari AVE untuk setiap konstruk dengan nilai korelasi antar konstruk dalam model. Validitas discriminant yang baik ditunjukan dari akar kuadrat AVE untuk tiap konstruk lebih besar dari korelasi antar konstruk dalam model. (Fornell dan Larcker, 1981 dalam Latan dan Ghozali, 2012). Nilai AVE direkomendasikan harus lebih besar dari 0,50. Hasil analisis nilai AVE ditunjukan dalam Tabel 2 dan Latent Variable Correlations (korelasi variabel laten) ditunjukan dalam Tabel 3 berikut ini.

Tabel 2. Average Variance Extracted (AVE)

\begin{tabular}{ll}
\hline \multicolumn{1}{c}{ Variabel } & AVE \\
\hline $\begin{array}{l}\text { Kualitas Kehidupan } \\
\text { (X1) }\end{array}$ & Kerja \\
\hline Motivasi (X2) & 0,534911 \\
\hline Kepuasan Kerja (Y1) & 0,666223 \\
\hline Kinerja (Y2) & 0,543215 \\
\hline Sumber : Output SmartPLS 20 M3 & 0,525807 \\
\hline
\end{tabular}

Sumber : Output SmartPLS 2.0 M3

Tabel 3. Latent Variable Correlations

\begin{tabular}{|c|c|c|c|c|}
\hline Variabel & $\mathrm{X} 1$ & $\mathrm{X} 2$ & Y1 & Y2 \\
\hline $\begin{array}{l}\text { Kualitas } \\
\text { (X1) }\end{array}$ & $\begin{array}{ll}\text { Kerja } & \\
& 1,000000 \\
\end{array}$ & & & \\
\hline Motivasi (X2) & 0,627514 & 1,000000 & & \\
\hline Kepuasan Kerja (Y1) & 0,659298 & 0,708866 & 1,000000 & \\
\hline Kinerja (Y2) & 0,230318 & 0,320084 & 0,431541 & 1,000000 \\
\hline
\end{tabular}

Sumber : Output SmartPLS 2.0 M3

Akar AVE untuk variabel kualitas kehidupan kerja (X1) adalah 0,731, variabel motivasi (X2) adalah 0,816, variabel kepuasan kerja (Y1) adalah 0,737 dan variabel kinerja (Y2) adalah 0,725. Dari hasil tersebut terlihat akar AVE dari setiap variabel memiliki nilai yang lebih besar daripada korelasi antar konstruk dalam model, sehingga dapat disimpulkan bahwa model telah memenuhi discriminant validity yang cukup.

\section{Pengujian Composite Reliability}

Composite reliability digunakan untuk menguji reliabilitas suatu konstruk. Rule of thumb yang biasanya digunakan untuk menilai reliabilitas konstruk yaitu nilai composite reliability harus lebih besar dari 0,7 . Hasil pengujian composite reliability ditunjukan pada Tabel 4 berikut ini.

Tabel 4. Hasil Pengujian Composite Reliability

\begin{tabular}{lcc}
\multicolumn{1}{c}{ Variabel } & $\begin{array}{l}\text { Composite } \\
\text { Reliability }\end{array}$ & Keterangan \\
\hline Kualitas Kehidupan Kerja (X1) & 0,851034 & Reliabel \\
\hline Motivasi (X2) & 0,888295 & Reliabel \\
\hline Kepuasan Kerja (Y1) & 0,825104 & Reliabel \\
\hline Kinerja (Y2) & 0,814994 & Reliabel \\
\hline
\end{tabular}

Sumber : Output SmartPLS 2.0 M3

Hasil pengujian composite reliability masing-masing variabel yang terlihat dalam Tabel 4 diatas menunjukan masing-masing variabel memiliki nilai composite reliability diatas 0,7 , sehingga dapat disimpulkan bahwa model dalam penelitian telah memenuhi composite reliability. 


\section{Pengujian Model Struktural (Inner Model)}

Pengujian model struktural (Inner model) dilakukan dengan melihat nilai $R$-Square pada persamaan antar variabel laten. Berdasarkan hasil pengolahan data dengan menggunakan SmartPLS diperoleh nilai koefisien determinasi $R$-Square seperti yang ditunjukan pada Tabel 5 berikut ini.

Tabel 5. Nilai R-Square

\begin{tabular}{ll}
\hline \multicolumn{1}{c}{ Variabel } & R Square \\
\hline Kualitas Kehidupan Kerja (X1) & \\
\hline Motivasi (X2) & \\
\hline Kepuasan Kerja (Y1) & 0,578369 \\
\hline Kinerja (Y2) & 0,193352 \\
\hline
\end{tabular}

Sumber : Output SmartPLS 2.0 M3

Berdasarkan nilai $R$-Square pada Tabel 5 diatas, maka selanjutnya digunakan untuk menghitung nilai predictive relevance $\left(Q^{2}\right)$ dengan menggunakan rumus berikut ini.

$$
\begin{aligned}
& \mathrm{Q}^{2}=1-\left(1-\mathrm{R}_{1}^{2}\right)\left(1-\mathrm{R}_{2}^{2}\right) \ldots . .\left(1-\mathrm{R}_{\mathrm{P}}^{2}\right) \\
& \mathrm{Q}^{2}=1-(1-0,578369)(1-0,193352) \\
& \mathrm{Q}^{2}=0,6598
\end{aligned}
$$

Dari hasil perhitungan tersebut diperoleh nilai predictive relevance $\left(Q^{2}\right)$ sebesar 0,6598 . Hal tersebut menunjukan bahwa $65,98 \%$ variabilitas pada variabel kinerja dijelaskan oleh variabel kualitas kehidupan kerja, motivasi dan kepuasan kerja. Sedangkan sisanya $34,02 \%$ dijelaskan oleh variabel lain yang tidak masuk kedalam model.

Hasil pengujian hipotesis dengan menggunakan Partial Least Squares (PLS) menunjukkan bahwa tiga hipotesis dinyatakan signifikan dan dua hipotesis dinyatakan tidak signifikan. Pengujian dilakukan dengan $t$ test (uji t) terhadap Path Coefficients antara variabel dependen dan variabel independen. Hasil pengujian hipotesis tersebut ditunjukkan pada Tabel 6 berikut ini.

Tabel 6. Hasil Pengujian Hipotesis

\begin{tabular}{lccccc} 
& $\begin{array}{c}\text { Original } \\
\text { Sample (O) }\end{array}$ & $\begin{array}{c}\text { Standard } \\
\text { Deviation } \\
(\text { STDEV) }\end{array}$ & $\begin{array}{c}\text { Standard } \\
\text { Error } \\
\text { (STERR) }\end{array}$ & $\begin{array}{c}\text { T Statistics } \\
(\mid \mathbf{O} / \mathbf{S T E R R})\end{array}$ & Keterangan \\
\hline $\mathbf{X 1}$-> Y1 & 0,353787 & 0,093595 & 0,093595 & 3,779961 & Signifikan \\
\hline $\mathbf{X 1}$-> Y2 & $-0,114372$ & 0,109481 & 0,109481 & 1,044682 & Tidak Signifikan \\
\hline $\mathbf{X 2}$-> Y1 & 0,486859 & 0,098269 & 0,098269 & 4,954334 & Signifikan \\
\hline $\mathbf{X 2}$-> Y2 & 0,065319 & 0,162496 & 0,162496 & 0,401977 & Tidak Signifikan \\
\hline $\mathbf{Y 1}$-> Y2 & 0,460643 & 0,10513 & 0,10513 & 4,381675 & Signifikan \\
\hline
\end{tabular}

Sumber : Output SmartPLS 2.0 M3

Pengujian hipotesis pertama menunjukkan koefisien jalur pengaruh kualitas kehidupan kerja terhadap kepuasan kerja adalah sebesar 0,353787 dan t-statistik sebesar 3,779961. Karena t-statistik > t-tabel 1,96 (3,779961 > 1,96), maka hipotesis yang menyatakan bahwa terdapat pengaruh signifikan kualitas kehidupan kerja terhadap kepuasan kerja pegawai administrasi Universitas Palangka Raya diterima. Hubungan antara kedua variabel tersebut searah dan memiliki tanda positif, sehingga dapat disimpulkan bahwa peningkatan dimensi-dimensi kualitas kehidupan kerja akan berpengaruh terhadap kepuasan kerja.

Pengujian hipotesis kedua menunjukkan koefisien jalur pengaruh motivasi terhadap kepuasan kerja adalah sebesar 0,486859 dan t-statistik sebesar 4,954334. Karena t-statistik > t-tabel 1,96 (4,954334 > 1,96), maka hipotesis yang menyatakan bahwa terdapat pengaruh signifikan motivasi terhadap kepuasan kerja pegawai administrasi Universitas Palangka Raya diterima. Hubungan antara kedua variabel adalah searah dan memiliki tanda positif, sehingga dapat disimpulkan bahwa peningkatan dimensi-dimensi motivasi akan berpengaruh terhadap kepuasan kerja. 
Pengujian hipotesis ketiga menunjukkan koefisien jalur pengaruh kualitas kehidupan kerja terhadap kinerja adalah sebesar -0,114372 dan t-statistik sebesar 1,044682. Karena t-statistik > t-tabel 1,96 (1,044682 > 1,96), maka hipotesis yang menyatakan bahwa terdapat pengaruh signifikan motivasi terhadap kepuasan kerja pegawai administrasi Universitas Palangka Raya ditolak. Hubungan kedua variabel tersebut negatif sehingga variabel kualitas kehidupan kerja tidak signifikan berpengaruh langsung terhadap variabel kinerja.

Pengujian hipotesis keempat menunjukkan koefisien jalur pengaruh motivasi terhadap kinerja adalah sebesar 0,065319 dan t-statistik sebesar 0,401977. Karena t-statistik > t-tabel 1,96 $(0,401977>1,96)$, maka hipotesis yang menyatakan bahwa terdapat pengaruh signifikan motivasi terhadap kinerja pegawai administrasi Universitas Palangka Raya ditolak. Hubungan kedua variabel adalah searah dan memiliki nilai positif, namun variabel motivasi tidak signifikan berpengaruh langsung terhadap variabel kinerja.

Pengujian hipotesis kelima menunjukkan koefisien jalur pengaruh kepuasan kerja terhadap kinerja adalah sebesar 0,460643 dan t-statistik sebesar 4,381675. Karena t-statistik > t-tabel 1,96 (4,381675> 1,96), maka hipotesis yang menyatakan bahwa terdapat pengaruh signifikan kepuasan kerja terhadap kinerja diterima. Hubungan antara kedua variabel adalah searah dan memiliki tanda positif, sehingga dapat disimpulkan bahwa peningkatan dimensi-dimensi kepuasan kerja akan berpengaruh terhadap kinerja.

Untuk pengujian hipotesis 6 dan hipotesis 7 dengan menggunakan Sobel Test (Uji Sobel) diperoleh hasil sebagai berikut:

Berdasarkan hasil pengujian hipotesis dengan menggunakan PLS diperoleh t-statistik X1->Y1 sebesar 3,779961 dan t-statistik Y1->Y2 sebesar 4,381675. Menggunakan alat hitung interaktif dari Kris Preachers untuk menguji Sobel Test, dimana t-statistik yang diperoleh dari output hasil analisis PLS tersebut digunakan sebagai input pembanding, sehingga diperoleh hasil perhitungan t-statistik sebesar 2,86212229 dan $p$-value sebesar 0,00420815. Karena t-statistik > t-tabel $(2,86212229>1,96)$ dan $p$-value $<0,05(0,00420815<0,05)$, maka dapat disimpulkan bahwa variabel kepuasan kerja adalah signifikan sebagai variabel intervening (mediasi) bagi pengaruh variabel kualitas kehidupan kerja terhadap kinerja, sehingga hipotesis yang menyatakan terdapat pengaruh signifikan kualitas kehidupan kerja secara tidak langsung terhadap kinerja melalui kepuasan kerja pegawai administrasi Universitas Palangka Raya diterima.

Hasil pengujian hipotesis dengan menggunakan PLS diperoleh t-statistik X2->Y1 sebesar 4,954334 dan Y1->Y2 sebesar 4,381675. Dengan menggunakan alat hitung interaktif dari Kris Preachers untuk menguji Sobel Test, diperoleh hasil perhitungan t-statistik sebesar 3,28218993 dan $p$-value sebesar 0,00103004. Karena t-statistik > t-tabel $(3,28218993>1,96)$ dan $p$-value $<0,05(0,00103004<0,05)$, maka dapat disimpulkan bahwa variabel kepuasan kerja adalah signifikan sebagai variabel intervening (mediasi) bagi pengaruh variabel motivasi terhadap kinerja sehingga hipotesis yang menyatakan terdapat pengaruh signifikan motivasi secara tidak langsung terhadap kinerja melalui kepuasan kerja pegawai administrasi pada Universitas Palangka Raya diterima.

Hasil pengujian hipotesis pertama menunjukan bahwa kualitas kehidupan kerja berpengaruh positif dan signifikan terhadap kepuasan kerja. Indikator total ruang hidup menjadi indikator utama didalam menggambarkan kualitas kehidupan kerja pada Universitas Palangka Raya. Dukungan organisasi Universitas Palangka Raya dengan menciptakan keseimbangan antara pekerjaan dan keluarga, jam kerja serta kondisi pekerjaan yang nyaman memberikan keseimbangan waktu bagi para pegawai didalam membagi tugas dan tanggungjawabnya sebagai pegawai dan juga tanggungjawabnya dalam kehidupan sosialnya bermasyarakat, sehingga dengan adanya keseimbangan tersebut para pegawai administrasi menjadi puas didalam pekerjaannya. Sedangkan persepsi responden terhadap indikator konstitusionalisme mendapatkan nilai paling rendah. Hal ini disebabkan karena para pegawai bagian administrasi masih belum mendapatkan kebebasan dalam berekspresi dan berpendapat serta kesempatan berpartisipasi dalam pengambilan keputusan, sehingga mereka memberikan tanggapan yang rendah terhadap indikator tersebut. Hasil pengujian hipotesis pertama ini mendukung penelitian sebelumnya yang dilakukan oleh Husnawati (2006) dan Hasanmoradi (2011) yang menyatakan bahwa kualitas kehidupan kerja berpengaruh positif dan signifikan terhadap kepuasan kerja.

Hasil pengujian hipotesis kedua menunjukkan bahwa motivasi berpengaruh positif dan signifikan terhadap kepuasan kerja. Responden memberikan persepsi yang tinggi terhadap indikator hubungan antar pribadi dalam motivasi. Hal ini menunjukkan bahwa terciptanya hubungan yang baik antar pribadi didalam lingkungan organisasi pada Universitas Palangka Raya mampu memberikan kepuasan kerja bagi para pegawai bagian administrasi terhadap pekerjaannya. Para pegawai administrasi merasa puas dengan adanya hubungan yang baik dan harmonis antara pegawai dengan atasannya maupun dengan sesama pegawai didalam organisasi Universitas Palangka Raya, karena kondisi tersebut menciptakan lingkungan dan situasi kerja yang kondusif 
dan menyenangkan bagi para pegawai, sehingga mereka memperoleh kenyamanan didalam bekerja dan merasa puas untuk selalu bekerja dengan baik dan dampaknya memberikan respon yang positif bagi para pegawai terhadap pekerjaannya. Sedangkan rendahnya persepsi responden terhadap indikator penghargaan disebabkan karena beberapa pegawai bagian administrasi Universitas Palangka Raya merasa penghargaan hanya bersifat simbolis yang hanya diberikan karena adanya usulan, bukan sebuah pemberian kepada sebuah prestasi yang sebenar-benarnya. Dengan melihat kondisi riil yang ada pada Universitas Palangka Raya, pemberian promosi serta bonus penghargaan terhadap pegawai lebih diutamakan dengan melihat tingkatan kepangkatan serta lamanya masa kerja dan sangat sedikit pegawai yang mendapatkan penghargaan atas dasar prestasinya, sehingga persepsi mereka rendah terhadap indikator penghargaan. Hasil pengujian hipotesis ini mendukung penelitian oleh Brahmasari (2008) dan penelitian Wiyono dan Hakim (2009) yang menyatakan bahwa motivasi berpengaruh positif dan signifikan terhadap kepuasan kerja.

Hasil pengujian hipotesis ketiga menunjukkan bahwa kualitas kehidupan kerja berpengaruh negatif dan tidak signifikan. Hasil pengujian hipotesis ini tidak konsisten dengan hasil penelitian Arifin (2012), Majumdar et al. (2012) serta Aketch et al. (2012) yang menyatakan bahwa kualitas kehidupan kerja berpengaruh terhadap kinerja. Jika melihat kondisi riil yang ada pada Universitas Palangka Raya, hal ini disebabkan karena para pegawai bagian administrasi terkesan cuek dan tidak peduli terhadap kondisi lingkungan pekerjaannya, disamping juga tidak meratanya pembagian pekerjaan pada setiap pegawai serta belum adanya standar baku untuk penilaian kinerja. Sehingga ketika organisasi berupaya untuk meningkatkan dimensi-dimensi kualitas kehidupan kerja agar mampu meningkatkan kinerja pegawai administrasi, para pegawainya tidak memberikan umpan balik dengan meningkatkan kinerjanya. Para pegawai tetap melakukan pekerjaannya seperti biasa, dimana pekerjaan yang dilakukan hanya dipandang sebagai rutinitas sehari-hari yang tidak menuntut hasil kerja yang optimal, sehingga peningkatan dimensi-dimensi kualitas kehidupan kerja untuk meningkatkan kinerja yang baik tidak tercapai.

Hasil pengujian hipotesis keempat menunjukan bahwa motivasi berpengaruh positif terhadap kinerja namun tidak signifikan. Hasil pengujian ini mendukung penelitian Brahmasari (2008) yang menyatakan bahwa motivasi berpengaruh positif namun tidak berpengaruh signifikan terhadap kinerja. Motivasi tidak berpengaruh secara langsung dengan kinerja jika tidak melalui kepuasan kerja. Melihat kondisi yang, hal ini dapat disebabkan karena para pegawai bagian administrasi merasa bahwa dimensi-dimensi motivasi tersebut masih belum merepresentasikan keinginan dan harapan para pegawai bagian administrasi dalam meningkatkan kinerjanya. Pemenuhan kebutuhan yang dirasakan fundamental serta komunikasi persuasif yang dilakukan organisasi Universitas Palangka Raya masih belum mampu memenuhi motivasi yang diharapkan para pegawai bagian administrasi untuk dapat meningkatkan kinerjanya, sehingga walaupun persepsi responden yang ditunjukkan terhadap variabel motivasi masuk dalam kategori tinggi, namun hubungannya terhadap kinerja pegawai tidak signifikan.

Hasil pengujian hipotesis kelima menunjukkan bahwa kepuasan kerja berpengaruh positif dan signifikan terhadap kinerja. Hasil pengujian ini mendukung hasil penelitian Hira dan Waqas (2012), Wiyono dan Hakim (2009), Arifin (2012), Brahmasari (2008) serta Husnawati (2006), dimana semuanya menyatakan bahwa kepuasan kerja berpengaruh positif dan signifikan terhadap kinerja. Hal ini berarti para pegawai bagian administrasi Universitas Palangka Raya merasa bahwa dimensi-dimensi kepuasan kerja tersebut apabila dapat dipenuhi serta didukung secara maksimal oleh organisasi Universitas Palangka Raya sesuai dengan harapan pegawai, maka akan meningkatkan kinerja mereka dalam melaksanakan pekerjaannya. Pegawai yang merasa puas dengan pekerjaannya sendiri serta merasa puas dengan besarnya gaji yang diterima dan juga mendapatkan peluang promosi serta didalam pekerjaannya mendapatkan dukungan dari sesama rekan kerja, akan selalu berusaha untuk berkinerja dengan baik. Persepsi responden terhadap kepuasan kerja menunjukan nilai persepsi responden yang berada dalam kategori sedang. Indikator rekan kerja menjadi persepsi responden tertinggi. Hal ini menunjukan bahwa pegawai yang mendapatkan dukungan dari rekan kerjanya dalam melaksanakan pekerjaannya akan mendorong pegawai tersebut untuk meningkatkan kinerjanya. Sedangkan persepsi responden rendah terhadap indikator gaji. Hal ini menunjukan bahwa pegawai bagian administrasi merasa struktur gaji gaji yang diterima masih belum memberikan kepuasan kerja bagi mereka untuk meningkatkan kinerjanya.

Dari hasil pengujian hipotesis yang telah dilakukan, ditemukan bahwa kualitas kehidupan kerja belum mampu memberikan implikasi yang signifikan terhadap kinerja secara langsung, namun apabila kualitas 
kehidupan kerja melalui kepuasan kerja, maka secara tidak langsung memberikan pengaruh terhadap kinerja. Variabel kepuasan kerja merupakan variabel intervening atau mediasi bagi pengaruh kualitas kehidupan kerja terhadap kinerja secara tidak langsung. Hal ini dibuktikan dengan melakukan Sobel Test menggunakan alat hitung interaktif dari Kris Preachers dimana diperoleh hasil yang signifikan pengaruh antara kualitas kehidupan kerja terhadap kinerja dengan melalui kepuasan kerja. Hasil pengujian ini mendukung penelitian sebelumnya yang dilakukan Husnawati (2006) yang menyatakan bahwa kualitas kehidupan kerja berpengaruh terhadap kepuasan kerja yang selanjutnya mempengaruhi kinerja karyawan. Semakin tinggi kepuasan yang dirasakan terhadap perusahaan, maka semakin baik pula kinerja ditunjukkan oleh karyawan. Hasil analisis ini menunjukkan bahwa peningkatan dimensi-dimensi kualitas kehidupan kerja akan memberikan pengaruh secara tidak langsung terhadap peningkatan kinerja para pegawai bagian administrasi Universitas Palangka Raya apabila diiringi dengan peningkatan kepuasan kerja yang diharapkan para pegawai. Pegawai bagian administrasi yang merasa puas terhadap peningkatan kualitas kehidupan kerja pada lingkungan akan terdorong untuk meningkatkan kinerjanya terhadap organisasi.

Hasil pengujian hipotesis menunjukkan bahwa variabel motivasi tidak berpengaruh signifikan secara langsung terhadap variabel kinerja, tetapi apabila melalui variabel kepuasan kerja maka variabel motivasi akan memberikan pengaruh terhadap variabel kinerja. Dari hasil analisis PLS diatas ditemukan koefisien jalur antara motivasi (X2) terhadap kinerja (Y2) secara langsung adalah sebesar 0,065 dan tidak signifikan lalu koefisien jalur antara motivasi (X2) ke kepuasan kerja (Y1) adalah sebesar 0,487 dan signifikan serta kepuasan kerja (Y1) ke kinerja (Y2) adalah sebesar 0,461 dan signifikan, sehingga dapat simpulkan bahwa model ini adalah complete mediation atau variabel mediasi sempurna. Variabel kepuasan kerja adalah variabel intervening (mediasi) bagi pengaruh variabel motivasi terhadap kinerja. Hal ini dibuktikan dari hasil Sobel Test yang menunjukan hasil yang signifikan pengaruh antara motivasi terhadap kinerja dengan melalui kepuasan kerja. Hasil pengujian ini mendukung penelitian sebelumnya yang dilakukan oleh Wiyono dan Abdul Hakim (2009) yang menyatakan bahwa motivasi berpengaruh signifikan terhadap kinerja dengan kepuaasan kerja sebagai variabel intervening. Hasil analisis tersebut menunjukkan bahwa peningkatan terhadap dimensi-dimensi motivasi akan meningkatkan kinerja para pegawai bagian administrasi Universitas Palangka Raya dan memberikan dampak dengan turut meningkatnya kinerja mereka didalam melaksanakan pekerjaannya. Pegawai bagian administrasi yang merasa puas terhadap dimensi-dimensi motivasi yang telah diberikan oleh organisasi secara tidak langsung akan meningkatkan kinerja mereka didalam melaksanakan pekerjaannya.

Implikasi teoritis merupakan gambaran teori-teori yang menjadi rujukan dalam penelitian ini, yang diperkuat keberadaannya dengan dukungan empiris mengenai hubungan kausalitas antar variabel yang mempengaruhi variabel kinerja. Berdasarkan hasil penelitian yang diperoleh dalam penelitian ini, dapat dikemukakan beberapa implikasi teoritis sebagai berikut. Pertama penelitian ini secara teoritis telah mampu memprediksi bahwa kualitas kehidupan kerja berpengaruh positif dan signifikan terhadap kepuasan kerja. Hasil penelitian ini secara empiris memperkuat hasil penelitian sebelumnya yang menyatakan kualitas kehidupan kerja berpengaruh positif terhadap kepuasan kerja (Husnawati (2006) dan Hasanmoradi (2011).Kedua motivasi berpengaruh positif dan signifikan terhadap kepuasan kerja. Hasil penelitian ini secara empiris mendukung hasil penelitian sebelumnya yang menyatakan bahwa motivasi berpengaruh positif dan signifikan terhadap kepuasan kerja (Brahmasari (2008) serta Wiyono dan Hakim (2009). Ketiga motivasi berpengaruh positif namun tidak signifikan terhadap kinerja. Hasil penelitian ini mendukung hasil penelitian sebelumnya yang menyatakan bahwa motivasi berpengaruh positif namun tidak signifikan. Motivasi tidak dapat berhubungan secara langsung dengan kinerja jika tidak melalui kepuasan kerja (Brahmasari (2008).Keempat kepuasan kerja berpengaruh positif dan signifikan terhadap kinerja. Hasil penelitian ini secara empiris mendukung hasil penelitian sebelumnya yang menyatakan bahwa kepuasan kerja berpengaruh positif dan signifikan terhadap kinerja (Hira dan Waqas (2012); Wiyono dan Hakim (2009); Arifin (2012); Brahmasari (2008) serta Husnawati (2006). Kelima kualitas kehidupan kerja berpengaruh signifikan terhadap kinerja melalui kepuasan kerja. Hasil penelitian ini mendukung hasil penelitian sebelumnya yang menyatakan kualitas kehidupan kerja berpengaruh terhadap kepuasan kerja yang selanjutnya mempengaruhi kinerja karyawan. Semakin tinggi kepuasan yang dirasakan terhadap perusahaan, maka semakin baik pula kinerja ditunjukkan oleh karyawan Husnawati (2006). Keenam motivasi berpengaruh signifikan terhadap kinerja melalui kepuasan kerja. Hasil penelitian ini mendukung hasil penelitian sebelumnya yang menyatakan bahwa motivasi berpengaruh signifikan terhadap kinerja dengan kepuaasan kerja sebagai variabel intervening Wiyono dan Abdul Hakim (2009). 
Keterbatasan Penelitian

Penelitian ini tidak terlepas dari keterbatasan dan ketidaksempurnaan didalamnya seperti standar penilaian kinerja untuk pegawai bagian administrasi yang menduduki jabatan pimpinan dengan pegawai bagian administrasi yang menduduki jabatan pelaksana adalah berbeda, sehingga pertanyaan yang diajukan melalui kuesioner memungkinkan terjadinya bias didalam jawaban antara pegawai yang menduduki jabatan pimpinan dengan pengawai yang menduduki jabatan pelaksana. Standar penilaian kinerja yang dipergunakan untuk mengukur kinerja dalam penelitian ini masih bersifat umum sehingga masih belum mencapai penilaian kinerja yang sebenar-benarnya untuk mengukur kinerja. Penelitian ini dilakukan pada Universitas Palangka Raya dimana seluruh pegawainya adalah pegawai PNS Pusat, sehingga memungkinkan munculnya persepsi responden yang berbeda apabila dilakukan pada pegawai PNS Daerah.

\section{SIMPULAN}

Berdasarkan rumusan masalah, tujuan penelitian, pengujian hipotesis serta pembahasan, maka dapat ditarik kesimpulan sebagai berikut. Pertama kualitas kehidupan kerja berpengaruh secara langsung terhadap kepuasan kerja. Pengaruh langsung tersebut ditunjukan positif dan signifikan antara kualitas kehidupan kerja terhadap kepuasan kerja. Kedua motivasi mempunyai pengaruh secara langsung terhadap kepuasan kerja. Hal ini ditunjukan dengan pengaruh positif dan signifikan anatara motivasi terhadap kepuasan kerja. Ketiga kualitas kehidupan kerja tidak berpengaruh secara langsung terhadap kinerja. Hal ini ditunjukan dengan pengaruh negatif dan tidak signifikan antara kualitas kehidupan kerja terhadap kinerja. Keempat motivasi tidak berpengaruh secara langsung terhadap kinerja. Pengaruh antara motivasi terhadap kinerja ditunjukan positif namun tidak signifikan. Kelima kepuasan kerja berpengaruh secara langsung terhadap kinerja. Hubungan antara kedua variabel tersebut positif dan signifikan. Keenam kualitas kehidupan kerja berpengaruh signifikan secara tidak langsung terhadap kinerja dengan melalui kepuasan kerja. Ketujuh motivasi berpengaruh signifikan secara tidak langsung terhadap kinerja dengan melalui kepuasan kerja.

Penelitian selanjutnya perlu dilakukan terhadap pegawai yang berstatus PNS daerah untuk mendapatkan persepsi yang berbeda tentang kualitas kehidupan kerja, motivasi, kepuasan kerja dan kinerja. Sebaiknya responden adalah pegawai yang memilki tingkatan jabatan yang sama sehingga mempunyai standar penilaian yang sama terhadap kinerjanya serta disarankan untuk mengembangkan teknik penilaian kinerja dengan merata-ratakan penilaian dari masing-masing atasan, rekan kerja serta diri sendiri untuk responden yang berbeda tingkatannya agar mendapatkan penilaian kinerja yang sebenar-benarnya dan nyata.

Perlunya memperhatikan dimensi-dimensi kualitas kehidupan kerja dimana dimensi-dimensi kualitas kehidupan kerja ini mampu meningkatkan kepuasan kerja para pegawai bagian administrasi yang secara tidak langsung meningkatkan kinerja mereka. Untuk dapat meningkatkan motivasi para pegawai bagian administrasi melalui peningkatan terhadap dimensi-dimensi motivasi dimana peningkatan terhadap dimensi-dimensi motivasi ini mampu memberikan peningkatan kepuasan kerja bagi para pegawai bagian administrasi yang secara tidak langsung meningkatkan kinerja mereka. Agar selalu meningkatkan dimensi-dimensi kepuasan kerja bagi para pegawai bagian administrasi diantaranya dengan menciptakan suasana keakraban dan kepedulian antar sesama pegawai didalam lingkungan pekerjaannya sehingga setiap pegawai akan memiliki rasa untuk saling mendukung antar sesama pegawai didalam melaksanakan pekerjaannya. Selain itu memberikan tambahan penghasilan berupa tunjangan kinerja yang sesuai dengan standar penilaian kinerja yang adil sehingga para pegawai bagian administrasi yang mendapatkannya akan merasa puas dalam pekerjaannya.

\section{DAFTAR RUJUKAN}

Aketch. J.R., Odera. O., Chepkuto. P dan Okaka. O. 2012. Effects of Quality of Work Life on Job Performance: Theoretical Perspectives and Literature Review. Current Research Journal of Social Sciences 4(5): 383-388, 2012 ISSN: 2041-3246.@ Maxwell Scientific Organization, 2012.

Al-Qutop. M.Y dan Harrim. H. 2011. Quality of Worklife Human Well-being Linkage: Integrated Conceptual Framework. International Journal of Business and Management Vol. 6, No. 8; August 2011. www.ccsenet.org/ijbm.

Arifin. N. 2012. Analisis Kualitas Kehidupan Kerja, Kinerja, dan Kepuasan Kerja Pada CV Duta Senenan Jepara. Jurnal Economia, Volume 8, Nomor 1, April 2012.

Azar. M dan Shafighi. A.A. 2013. The Effect of Work Motivation on Employees' Job Performance (Case Study: Employees of Isfahan Islamic Revolution Housing Foundation). International Journal of 
Academic Research in Business and Social Sciences September 2013, Vol. 3, No. 9 ISSN: 2222-6990. Baleghizadeh. S dan Gordani. Y. 2012. Motivation and Quality of Work Life among Secondary School EFL Teachers. Australian Journal of Teacher Education. Volume 37 | Issue 7 Article 3. 2012.

Brahmasari I. A. dan Suprayetno. A. 2008. Pengaruh Motivasi Kerja, Kepemimpinan dan Budaya Organisasi Terhadap Kepuasan Kerja Karyawan serta Dampaknya pada Kinerja Perusahaan (Studi kasus pada PT. Pei Hai International Wiratama Indonesia). JURNAL MANAJEMEN DAN KEWIRAUSAHAAN, VOL.10, NO. 2, SEPTEMBER 2008: 124-135.

Budianto. 2013. Pengaruh Motivasi Intrinsik dan Motivasi Ekstrinsik terhadap Kinerja Pegawai melalui Kepuasan Kerja (Studi pada Universitas Palangka Raya). Tesis. Program Studi Magister Sains Manajemen, Program Pasca Sarjana Universitas Palangka Raya. Palangka Raya.

Chintalloo. S dan Mahadeo. J.D. 2013. Effect of Motivation on Employees' Work Performance at Ireland Blyth Limited. Proceedings of 8th Annual London Business Research Conference Imperial College, London, UK, 8 - 9 July, 2013, ISBN: 978-1-922069-28-3.

Duyan, Emin C., Aytac, Serpil., Akyıldız, Neslihan dan Darren Van Laar. 2013. Measuring Work Related Quality of Life and Affective Well-Being in Turkey. ISSN 2039-9340. Mediterranean Journal of Social Sciences. Vol. 4 (1) January 2013.

Ferdinand. A. 2011. Metode Penelitian Manajemen Pedoman Penelitian untuk Penulisan Skripsi, Tesis, dan Disertasi Ilmu Manajemen. Edisi Ketiga. Semarang : Badan Penerbit Universitas Diponegoro.

Gibson. J.L., Ivancevich. J.M., J.H. Donnelly, Jr dan Konopaske. R. 2012. Organizations ; Behaviour, Structure, Processes. Fourteenth Edition. McGraw-Hill. New York.

Hasanmoradi. N. 2011. Relationship Between The Quality Of Work Life and Job Satisfaction Among The Teachers Of Public and Non-Public Schools in Tehran. International Journal of Arts \& Sciences (CDROM). ISSN: 1944-6934::4(25):279-285 (2011) Copyright c 2011 by InternationalJournal.org.

http://quantpsy.org/sobel/sobel.htm. Calculation for the Sobel test: An interactive calculation tool for mediation tests. Preacher, K. J.

Hira. A dan Wakas. I. 2012. A Study of Job Satisfaction and IT's Impact on the Performance in the Banking Industry of Pakistan. International Journal of Business and Social Science Vol. 3 No. 19; October 2012.

Husnawati. A. 2006. Analisis Pengaruh Kualitas Kehidupan Kerja terhadap Kinerja Karyawan dengan Komitmen dan Kepuasan Kerja sebagai intervening variabel (Studi pada PERUM Pegadaian Kanwil VI Semarang). Tesis. Program Pasca Sarjana Pada Program Magister Manajemen Universitas Diponegoro. Semarang.

Istijanto. O. 2010. Riset Sumber Daya Manusia. Cara Praktis Mengukur Stress, Kepuasan Kerja, Komitmen, Loyalitas, Motivasi Kerja, dan Aspek-Aspek Kerka Karyawan Lainnya. Edisi Revisi. PT. Gramedia Pustaka Utama. Jakarta.

Kusumawati. R. 2008. Analisis Pengaruh Budaya Organisasi dan Gaya Kepemimpinan terhadap Kepuasan Kerja untuk meningkatkan Kinerja Karyawan (Studi Kasus Pada RS. Roemani Semarang). Tesis. Program Studi Magister Manajemen, Program Pasca Sarjana Universitas Diponegoro. Semarang.

Latan, Hengky dan Ghozali, Imam. 2012. Partial Least Squares : Konsep, Teknik dan Aplikasi SmartPLS 2.0 M3 Untuk Penelitian Empiris. Badan Penerbit Universitas Diponegoro, Semarang.

Luthans. Fred. 2011. Organizational Behaviour; An Evidence-Based Approach. 12th Edition, McGraw-Hill. Ney York.

Majumdar. M.N., Dawn. D dan Dutta. A. 2012. Impact Quality Work-life on Job Performance : A Case Study on Indian Telecom Sector. International Journal of Arts \& Sciences (CD-ROM). ISSN: 1944-6934 : 5(6):655-685 (2012) Copyright c 2012 by UniversityPublications.net.

Mangnga,' Dwi A. R. 2012. Kinerja Pegawai Di Dinas Kelautan dan Perikanan Provinsi Sulawesi Selatan. Skripsi. Universitas Hasanuddin Fakultas Ilmu Sosial dan Ilmu Politik Jurusan Ilmu Administrasi Program Sarjana. Makassar.

Moorhead. G dan Griffin. R.W. 2013. Perilaku Organisasi ; Manajemen Sumber Daya Manusia dan Oganisasi. Edisi 9. Salemba Empat. Jakarta Selatan.

Prasanga. A.P. Amila dan Gamage. Aruna S. 2012. Job Satisfaction and Job Performance of the Sailors in Rapid Action Boat Squadron of Sri Lanka Navy. Sri Lankan Journal of Human Resource Management Vol.3, No.1, 2012.

_.Profil Universitas Palangka Raya. 2012. Sub Bagian Humas Universitas Palangka Raya.

Riduan. 2008. Metode dan Teknik Menyusun Tesis. Alfabeta. Bandung 
Siregar. S. 2010. Statistika Deskriptif Untuk Penelitian. PT. Raja Grafindo Persada. Jakarta.

Solimun. 2014. Analisis Multivariat : Pemodelan Persamaan Struktural, Analisis Jalur dan SEM Serta PLS.

Makalah Pelatihan Analisis Multivariat Program Studi Magister Sains Manajemen Pascasarjana

Universitas Palangka Raya. Program Studi Statistika Fakultas MIPA, Universitas Brawijaya. Malang. Sugiyono. 2012. Metode Penelitian Kuantitatif, Kualitatif Dan $R$ \& D. Alfabeta. Bandung.

Uche. A.L., Fiberesima. D dan Christiana. A. O. 2011. Relationship Between Motivational Factors and Teachers' Performance on the Job in Ogba/ Egbema/ Ndoni Local Government Area, of Rivers State. ISSN 2039-2117 Mediterranean Journal of Social Sciences Vol. 2 (5) October 2011.

Umam. K. 2010. Perilaku Organisasi. CV. Pustaka Setia. Bandung

Wiyono dan Hakim, A. 2009. Pengaruh Gaya Kepemimpinan, Motivasi dan Kemitraan serta Kepuasan Kerja terhadap Kinerja Pegawai. JRBI Vol. 5, No. 1, Januari 2009. 